\title{
NEW RECORDS OF DEEP-SEA CUSK EELS,DICROLENE TRISTIS AND BASSOZETUS MULTISPINIS (OPHIDIIFORMES: OPHIDIIDAE) FROM TAIWAN
}

\author{
Mao-Ying Lee \\ Marine Fisheries Division, Fishery Research Institute, No. 199, He 1st Road, Keelung, Taiwan 202, R.O.Department of \\ Aquaculture, National Taiwan Ocean University, No. 2,Pei-Ning Road, Keelung, Taiwan 202, R.O.C \\ Ding-An Lee \\ Marine Fisheries Division, Fishery Research Institute, No. 199, He 1st Road, Keelung, Taiwan 202, R.O.C \\ Hong-Ming Chen \\ Department of Aquaculture, National Taiwan Ocean University, No. 2, Pei-Ning Road, Keelung, Taiwan 202, R.O.C., \\ hmchen@mail.ntou.edu.tw
}

Follow this and additional works at: https://jmstt.ntou.edu.tw/journal

Part of the Marine Biology Commons

\author{
Recommended Citation \\ Lee, Mao-Ying; Lee, Ding-An; and Chen, Hong-Ming (2005) "NEW RECORDS OF DEEP-SEA CUSK EELS,DICROLENE \\ TRISTIS AND BASSOZETUS MULTISPINIS (OPHIDIIFORMES: OPHIDIIDAE) FROM TAIWAN," Journal of Marine Science \\ and Technology. Vol. 13: Iss. 2, Article 6. \\ DOI: $10.51400 / 2709-6998.2111$ \\ Available at: https://jmstt.ntou.edu.tw/journal/vol13/iss2/6 \\ This Research Article is brought to you for free and open access by Journal of Marine Science and Technology. It has been \\ accepted for inclusion in Journal of Marine Science and Technology by an authorized editor of Journal of Marine Science and \\ Technology.
}




\title{
NEW RECORDS OF DEEP-SEA CUSK EELS, DICROLENE TRISTIS AND BASSOZETUS MULTISPINIS (OPHIDIIFORMES: OPHIDIIDAE) FROM TAIWAN
}

\author{
Mao-Ying Lee*,**, Ding-An Lee*, and Hong-Ming Chen**
}

Key words: new record, deep-sea, Ophidiidae, basibranchial teeth patch.

\begin{abstract}
This paper reports two new record species of deep-sea cusk eels, Dicrolene tristis and Bassozetus multispinis, which were recently collected by Fishery Research Institute of Taiwan from the southern $\left(22^{\circ} 01^{\prime} \mathrm{N}, 120^{\circ} 09^{\prime} \mathrm{E} ; 22^{\circ} 11^{\prime} \mathrm{N}, 121^{\circ} 02^{\prime} \mathrm{E}\right)$ and eastern $\left(24^{\circ} 16^{\prime} \mathrm{N}\right.$, $122^{\circ} 11^{\prime} \mathrm{E}$ ) Taiwan waters at depths more than $1000 \mathrm{~m}$. D. tristis were characterized by two median and a pair of basibranchial teeth patches; B. multispinis had one basibranchial teeth patch and short pelvic fin ray. The latter species was reported to be only distributed in the Indian ocean at the depths from 1,500-2,000 m.
\end{abstract}

\section{INTRODUCTION}

The first catalogue of Ophidiiformes was published by Cohen and Nielsen [3], which mainly focused on the genus level, and the species classification were not complete. Later on, Nielsen et al. [8] published another catalogue that included all ophidiiformes fishes of the world. The earlier synopsis of Ophidiiformes fishes in Taiwan was written by Chen and $\mathrm{Yu}$ [2], which reported 2 families, 11 genera and 16 species. Chen and Shao [1] reported 7 species of Ophidiidae and 2 species of Bythitidae which was the only scientific report of Ophidiidae in Taiwan. The last publication was a part of "Fishes of Taiwan" edited by Shen et al. [11]. The book listed 3 families, 12 genera and 18 species belonging to Ophidiiformes. But these literatures only described the species in the inshore or continental shelf.

In recent years, Fishery Research Institute (FRI) and Institute of Zoology, Academia Sinica (ASIZ) started

Paper Submitted 11/10/04, Accepted 03/02/05. Author for Correspondence: Hong-Ming Chen. E-mail: hmchen@mail.ntou.edu.tw.

*Marine Fisheries Division, Fishery Research Institute, No. 199, He 1st Road, Keelung, Taiwan 202, R.O.C.

**Department of Aquaculture, National Taiwan Ocean University, No. 2, Pei-Ning Road, Keelung, Taiwan 202, R.O.C. to investigate the deep-sea fish fauna. A series deep-sea investigation collected many rare specimens. Among these specimens, many species had not been recorded in Taiwanese waters before. In the present study, we newly recorded two ophidiid fishes belonging to 2 genera from Taiwan; Dicrolene tristis and Bassozetus multispinis. These specimens were caught by French beam trawls at depths 1,000-3,000 m and caught by R/ V Fishery Researcher I.

\section{MATERIALS AND METHODS}

Two specimens of Dicrolene tristis were collected from southern Taiwan area at depths 1,128-1,197 m, and one specimen of Bassozetus multispinis from eastern Taiwan at depth 2,902 m. Collection localities of specimens of Bassozetus multispinis and Dicrolene tristis were showed in Figure 1. These specimens were preserved by FRI in Keelung.

The terminology and description of morphometrics of the fish followed Nielsen et al. [8]; Body proportions were expressed in term of standard length (SL: length from the snout tip to the base of caudal fin) and head length (HL: length of snout tip to the posterior margin of opercle). We also counted vertebrae and fin rays of the fish.

\section{RESULTS AND DISCUSSION}

Dicrolene tristis Smith and Radcliff, 1913

Figures (2A, 2B, 3A)

Dicrolene tristis Smith and Radcliff, 1913: 145, pl. 8, Figure 2; Masuda et al., 1984: 100, pl. 85; Nielsen et al., 1999: 62; Nakabo, 2000: 439.

Material examined:

FRI 0060730, SL $183 \mathrm{~mm}$, south Taiwan $\left(22^{\circ} 01^{\prime} \mathrm{N}\right.$, 
$\left.120^{\circ} 09^{\prime} \mathrm{E}\right)$, French beam trawl, $1,128 \mathrm{~m}$, July 30 , 2000. FRI 0060801, SL $158 \mathrm{~mm}$, south Taiwan $\left(22^{\circ} 11^{\prime} \mathrm{N}\right.$, $\left.121^{\circ} 02^{\prime} \mathrm{E}\right)$, French beam trawl, 1,197 m, August 1, 2000 .

\section{Diagnosis:}

Snout blunt; eye diameter almost as long as snout length; opercle had one strong, straight spine; and 3 developed spines at hind region of preopercle; lower rays of pectoral fins are free; about 5 to 7 rays and longer than upper ones. 2 median and a pair of basibranchial teeth patches.

\section{Description:}

Meristics: Dorsal fin rays: $98-101 \mathrm{~mm}$; anal fin rays: $78-85 \mathrm{~mm}$; pelvic fin rays: 2 ; pectoral fin rays: 27-30 mm; lower free rays of pectoral fins: 7-10 mm; caudal fin rays: 6 ; total vertebrae: $62 \mathrm{~mm}$; precaudal vertebrae: $15-16 \mathrm{~mm}$.

\section{Morphometrics in SL (\%):}

Head length: 17.7-18.2; predorsal length: 22.423.8; preanal length: $38-38.3$; pectoral fin length: 19.1 22.2; pelvic fin length: 6.3-6.6; body depths of first dorsal fin base: 15.9-16.8; length or dorsal fin base: 73 . 5-76.4; length of anal fin length: 58.3-61.5.

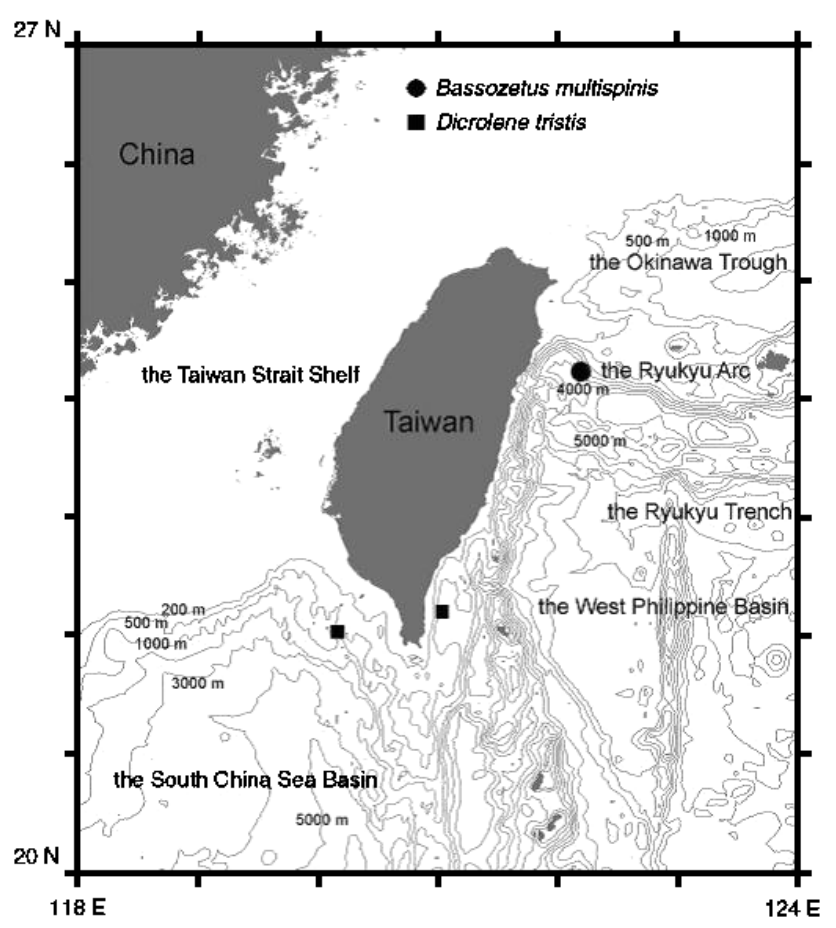

Fig. 1. Collection localities of specimens of Bassozetus multispinis and Dicrolene tristis that examined in this study.
Morphometrics in HL (\%):

Eye diameter: 24-29.1; snout length: 21.9-24.8.

Snout blunt; eye large; eye diameters almost equal to snout length; mouth large, upper jaw ends below posterior margin of eye or behind eye. Premaxilla had 2 palatine and a vomer teeth patches; opercular spine strong and straight. 3 broad, straight and short spines at hind margin of preopercle; 2 median and 2 basibranchial teeth patches(Figure 3A); pseudobranchial filaments 2 to 3 ; developed rakers on anterior gill arch 11-14.

Body elongated; general coloration pale; yellowish, no blotches and spots on body; small, cycloid scales covered ; preanal length about twice of head length; pelvic fin placed below preopercle; lower 7 to 10 rays of pectoral fin were free and longer; dorsal fin and anal fin connected with caudal fin; each pelvic fin had 2 separated rays.

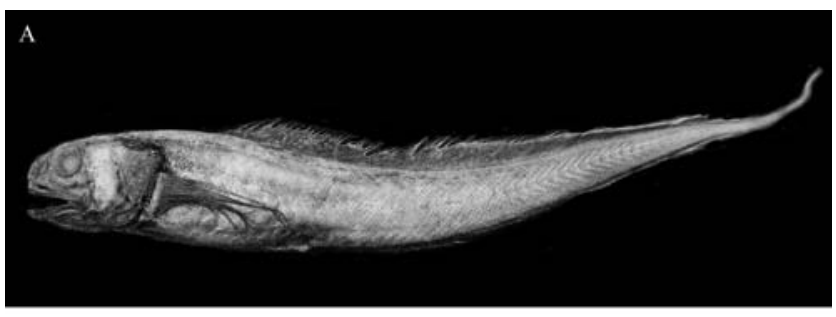

$\mathrm{B}$

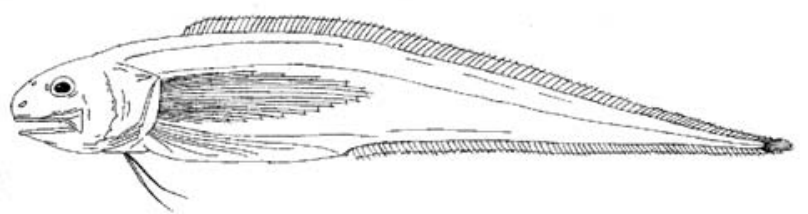

Fig. 2. Lateral view of Dicrolene tristis, FRI 0060801, $158 \mathrm{~mm}$ in SL, photograph (A) and diagram (B).

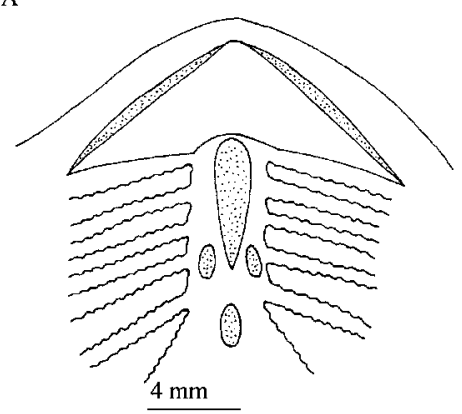

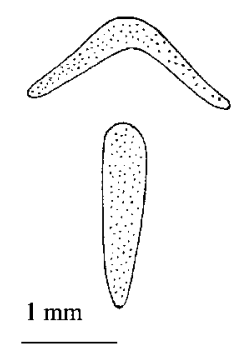

Fig. 3. (A) Basibranchial and median teeth patches of Dicrolene tristis, FRI 0060801; (B) vomer and basibranchial teeth patches of Bassozetus multispinis, FRI 0060803. 


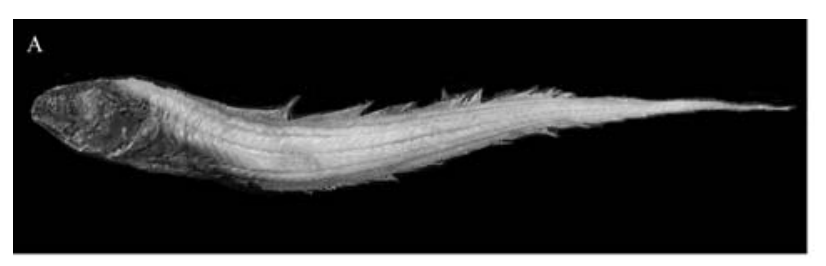

B

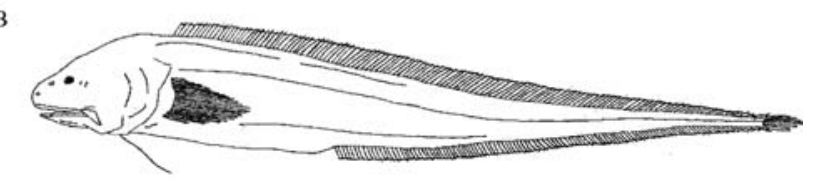

Fig. 4. Lateral view of Bassozetus multispinis, FRI 0060803, $171 \mathrm{~mm}$ in SL, photograph (A) and diagram (B).

Remark:

The species identification of genus Dicrolene was based on Nielsen et al. [8]. Main difference among species of the genus Dicrolene were the numbers of median basibranchial teeth patch and its comparative location. We considered that the allopatric distribution of similar species of Dicrolene can be used to identify the species of our two specimens. But this genus did not have complete revision what maybe due to similar characters among species.

\section{Bassozetus multsipinis Shcherbachev, 1980} Figures (3B, 4A, 4B)

Bassozetus multispinis Shcherbachev, 1980: 124, Figure 1; Nielsen et al., 1999: 58; Nielsen and Merrett, 1999: 36 .

Material examined:

FRI 0060803, SL $164 \mathrm{~mm}$, east Taiwan $\left(24^{\circ} 16^{\prime} \mathrm{N}\right.$, $122^{\circ} 11^{\prime}$ E), French beam trawl, 2,902 m, August 3, 2000.

Diagnosis:

Snout rather blunt, inflated; mouth terminal and large; eye very small, and eye diameter shorter than snout length; opercular spine weak and almost disappeared, teeth granular, vomer v-shaped and one well-developed basibranchial teeth patch; 17 developed gill rakers on anterior gill arch; one ray on each pelvic fin, and pelvic fin ray short.

\section{Description:}

Meristics: Dorsal fin rays: 127; anal fin rays: 112 ; pelvic fin rays: 1 ; pectoral fin rays: 23 ; caudal fin rays: 8 ; total vertebrae: 73 ; precaudal vertebrae: 15 .

Morphometrics in SL(\%):

Head length: 16.3; predorsal length: 15.7; preanal length: 29.5; pelvic fin length: 6.9 ; body depths at first anal fin: 7.5 ; length of dorsal fin base: 84.3 ; length of anal fin base: 69.7; upper jaw length: 9.5; base of pelvic fin to anal fin: 17.6 .

\section{Morphometrics in HL(\%)}

Eye diameter: 7.9; snout length: 24.5.

Snout rather blunt; eye small; eye diameters shorter than snout, only $32 \%$ of snout length; mouth large and terminal, upper jaw ends behind eye; opercular spine weak; no spine in preopercle; one well-developed basibranchial teeth patch; pseudobranchial filaments 2; 17 developed gill rakers on anterior gill arch.

Body compressed and elongated; tail long and attenuate, head swollen; head length about onehalf of preanal length; coloration of body and head were uniformly dark brown when specimen were caught. Body become pale and a little yellowish when preserved in alcohol, but head color was still dark brown. Body no any blotches or spots and covered by small, cycloid scales; dorsal and anal fins connected with caudal fin. Origin of dorsal fin base was above the upper of gill opening, pectoral fin damaged but maybe not reached to anus. Pelvic fins were below the preopercle and length of the rays were short.

Remark:

Generic diagnosis of Bassozetus based on Nielsen and Merrett [9], was following two diagnostic characters; median teeth patches and length of pelvic fin. We also compared with other literatures (Machida, [4]; Machida and Tachibana, [5]), and found out that the counts of precaudal, total vertebrae and proportion of standard length were different from other species. But in numbers of developed gill rakers, one median basibranchial teeth patch and short pelvic fin ray are similar to $B$. multispinis. Although the proportion of pelvic fin length was larger than any recorded specimen (6.9 vs. 3.0), Nielsen and Merrett [9] suggested this morphometric character showed negative allometric growth, and the specimen of FRI was smaller than the other specimen (SL 164 vs. 215). Thus, we identified FRI 0060803 as B. multipinis, which only known from eastern Indian Ridge in southern Indian Ocean at depths between 1,500 to $2,000 \mathrm{~m}$. 


\section{ACKNOWLEDGEMENTS}

We thank Fishery Research Institute in Taiwan for the supply of specimens and equipments, and Dr. Wu, Ji-Luen (FRI), Dr. Shao, Kwang-Tsao (ASIZ) and Dr. Yeh, Hsin-Ming (ASIZ) for the valuable comments and suggestions in the manuscript.

\section{REFERENCES}

1. Chen, L.J. and Shao, K.T., "A Review of the Families Ophidiidae and Bythitidae from Taiwan," Bull. Inst. Zool. Acad. Sin., Vol. 30, No. 1, pp. 9-18 (1991).

2. Chen, J.T.F. and Yu, M.J., A Synopsis of the Vertebrates of Taiwan, Commercial Books Co., Taipei, Taiwan, Vol. 1, pp. 337-341 (1986).

3. Cohen, D.M. and Nielsen, J.G., "Guide to the Identification of Genera of the Fish Order Ophidiiformes with a Tentative Classification of the Order," NOAA Tech. Rep. NMFS Circ., Vol. 417, pp. 1-72 (1978).

4. Machida, Y., "A New Deep-sea ophidiid Fish, Bassozetus levistomatus, from the Izu-Bonin Trench Japan," Jpn. J. Ichthyol., Vol. 36 , No. 2, pp. 187-189 (1989).

5. Machida, Y. and Tachibana, Y., "A New Record of Bassozetus zenkevitchi (Ophidiidae, Ophidiiformes) from Japan," Jpn. J. Ichthyol., Vol. 32, No. 4, pp. 437-439 (1986) .
6. Masuda, H., Amaoka, K., Araga, C., Uyeno, T., and Yoshino, T., The Fishes of the Japanese Archipelago, Tokai University Press, Japan, p. 100 (1984).

7. Nakabo, T., Fishes of Japan with Pictorial Keys to the Species, Tokai University Press, Japan, pp. 436-444 (2000).

8. Nielsen, J.G., Cohen, D.M., Markle, D.F., and Robins, C.R., FAO Species Catalogue: Ophidiiform Fishes of the World (Order: Ophidiiformes), FAO, Rome, Vol. 18, pp. 55-62 (1999) .

9. Nielsen, J.G. and Merrett, N.R., "Revision of the Cosmopolitan Deep-sea Genus Bassozetus (Pisces: Ophidiidae) with two New Species," Galathea Rep., Vol. 18, pp. 756 (1999).

10. Shcherbachev, Y.N., "Preliminary Review of Deep-sea Ophidiids (Ophidiidae, Ophidiiformes) of the Indian Ocean," Trudy Inst. Okeanol. Akad. Nauk. SSSR, Vol. 110, pp. 105-176 (1980).

11. Shen, S.C., Lee, S.C., Shao, K.T., Mok, H.K., Che, C.T., and Tzeng, C.S., Fishes of Taiwan, Department of Zoology, National Taiwan University, Taipei, Taiwan, pp. 174-176 (1993).

12. Smith, H.M. and Radcliff, L., "Descriptions of Seven New Genera and Thirty-one New Species of Fishes of the Families Brotulidae and Carapidae from the Philippine Islands and the Dutch East Indies," Proc. U. S. Natl. Mus., Vol. 44, pp. 135-176 (1913). 